AGH DRILLING, OIL, GAS • Vol. 32 • No. $2 \cdot 2015$

http://dx.doi.org/10.7494/drill.2015.32.2.289

Katarzyna Kosowska*, Piotr Kosowski**

\title{
25 YEARS OF GAZPROM ON THE GAS MARKET
}

\section{INTRODUCTION}

Gas sector belonged to one of the best developing branches of Russian industry over the last decades of the Soviet Union. It was possible thanks to the discovery of natural gas fields in Western Siberia in the 1960s and 1970s, followed by launching natural gas production and construction of transmission infrastructure, i.e. gas pipelines across Soviet Union and abroad. The history of Russian gas industry is inseparably connected with Gazprom, a concern established in 1989 in the place of the former Soviet Ministry of Gas Industry. Gazprom is composed of companies responsible for the geological and prospecting activity, production, processing, transmission, distribution and storage of natural gas. Gazprom production amounts to $74 \%$ of Russian and $14 \%$ of World's gas extraction (2013) [30].

Two stages can be distinguished in Gazprom history:

- I stage - Chernomyrdin-Viakhirev period (1991-2000),

- II stage - Miller period (2001-2014),

These periods considerably differ in, e.g.:

- gas prices and financial condition of the Concern,

- type of activities undertaken by the State in reference to Gazprom,

- relations between Gazprom and CIS countries.

* Jagiellonian University, Faculty of International and Political Studies, Krakow, Poland

** AGH University of Science and Technology, Faculty of Drilling, Oil and Gas, Krakow, Poland 


\section{GAS PRICES AND FINANCIAL CONDITION OF GAZPROM}

\subsection{Gas prices for domestic customers}

At the beginning of the 1990s Gazprom, with its founder V. Chernomyrdin, controlled the entire natural gas production in Russia (800 bn $\mathrm{m}^{3}$ annually), transmission (gas pipelines $160,000 \mathrm{~km}$ long), processing and storing. After the breakup of the Soviet Union gas industry was better off than other fuel-energy sectors, although Gazprom lost part of its assets in the former SU republics - about $25 \%$ of total compressor stations, over $30 \%$ of pipeline networks and $30 \%$ of underground gas storage capacities [19]. The major pipelines running from Russia to Europe started to be controlled by the CIS countries.

The transition from centralized economy of the former Soviet Union to a free market option was realized through the 'shock therapy'" under Yegor Gaidar, a young economist in Boris Yeltsin government. After introducing price liberalization in January 1992 the Russian economy was in a deep crisis. It started to recover under the sponsorship of energy sector, the only branch of industry where State-regulated prices were in power. Gazprom compensated for the artificially lowered gas prices in Russia by high export prices. Unfortunately about $70 \%$ of Russian gas was directed to the domestic market and the losses were huge [24]. The economic break-down and social disturbances in 1990s could be avoided largely thanks to Gazprom, who neither could increase the domestic prices for natural gas to the level of World's prices nor disconnect debtor gas clients. Thanks to the low gas prices the Concern subsidized Russian economy and companies running bankrupt. The debt level of gas customers resulted in cash-flow difficulties for Gazprom. Four raises of domestic prices for natural gas in the beginning of 1993 did not improve the financial condition of Gazprom, but only increased the amount debt to be paid off [19]. In December 1996, 19 years ago, Gazprom established a company Mezhgiongaz (MRG) responsible for the collectivity of receivables. Since 2008 MRG has regularly reported losses. According to data of 2013 the loss amounted to $28.83 \mathrm{bn}$ RUR. About $80 \%$ of debt came from the Northern Caucasus regions. On the 1 October 2014 the debt of Russian consumers totaled to 118.2bn RUR (3bn USD) [26].

As already noted, the biggest problem of the gas monopolist since the former Soviet Union breakup were the low gas prices on the domestic market. According to some specialists, this resulted in higher export gas deliveries at expense of the domestic market.

Since 2002 the gas prices in the State-regulated segment in Russia have increased year by year. In May 2007 the Government issued a decree No. 333 [22], which assumed the equalization of gas prices for the Russian and foreign markets in 2011. However, a rapid increase of oil prices in 2007 and in the first half of 2008 and the World's financial crisis imposed certain corrections. At the end of 2010 a governmental resolution No. 1205 about

1 "shock therapy" - plan of economy improvement lying in immediate transition to market economy, liberalization of prices and privatization of companies. 
amendments to the State regulation of gas prices [23] entered into force. Pursuant to this regulation the transition period was prolonged to the year 2014.

In the years 2000-2008 the gas prices increased from 220 to 1266 RUB for individual consumers, and from 351 to 1711 RUB for industry. According to experts gas sales to most of the domestic consumers (apart from households, i.e. 20\% of customers) were profitable [12]. The gas prices in USD for different categories of clients are presented in the Figure 1.

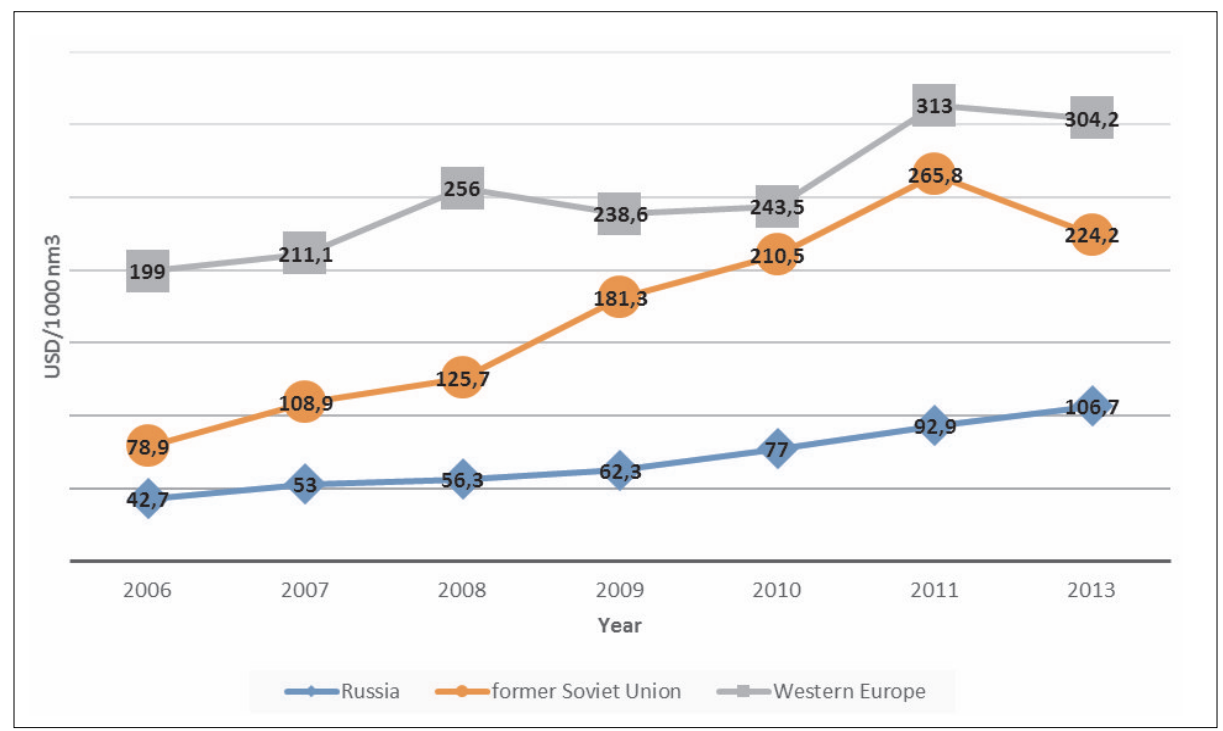

Fig. 1. Average price of gas sold by Gazprom (USD/1000 $\left.\mathrm{m}^{3}\right)$ Source: www.gazprom.ru/about/marketing/europe/

The State-regulated prices policy has recently weakened the competitiveness of Gazprom on the domestic market. In 2012 the participation of this gas monopolist on the domestic market amounted to $73 \%$ as compared to $76 \%$ in the year before. In 2013 Gazprom delivered $228 \mathrm{bn} \mathrm{m}^{3}$ of gas to the domestic market, i.e. $8.7 \%$ less than in 2012. The average wholesale State-regulated price of gas on domestic market equaled to 3393.9 RUB for $1000 \mathrm{~m}^{3}$ (no VAT included) [30]. Gazprom plans to maintain its participation in the domestic market at a level of $75 \%$ by 2020 . The drop of the participation in the market will be compensated by the planned gas deliveries to Siberia and Far East [3].

Since 2015 the Russian gas monopolist was offered consumer rebates on the domestic market. When realizing the previous price policy the concern was losing with the remaining players on the domestic gas market in the most attractive segment, i.e. industry. Both Novatek and Rosneft were not limited by State-regulated prices, and could offer more advantageous delivery conditions. This state has caused that in 2013 Gazprom supplied 228bn m ${ }^{3}$ of gas to the domestic market, as compared to 265 and $250 \mathrm{bn} \mathrm{m}^{3}$ in 2011 and 2012, respectively [4]. 


\subsection{Financial condition and production}

On the background of general break-down in the 1990s Gazprom's position remained relatively stable. The company slightly decreased its natural gas production due to the rapid drop of gas demand in Russia. At that time the Concern provided 94\% of domestic production from three biggest gas fields in the Western Siberia: Medvezhe, Urengoy and Yamburg, constituting $75 \%$ of annual gas production (Fig. 2) [13]. Despite the financial difficulties at that time Gazprom launched a few new fields.

After the economic break-down in the 1990s and the final financial crisis of 1998, the first presidency of V. Putin met the time when the Russian economy started to dynamically develop in almost all sectors. High gas prices did not have an effect on the better financial situation of Gazprom. The growth observed by the Concern after the year 2000 was relatively small.

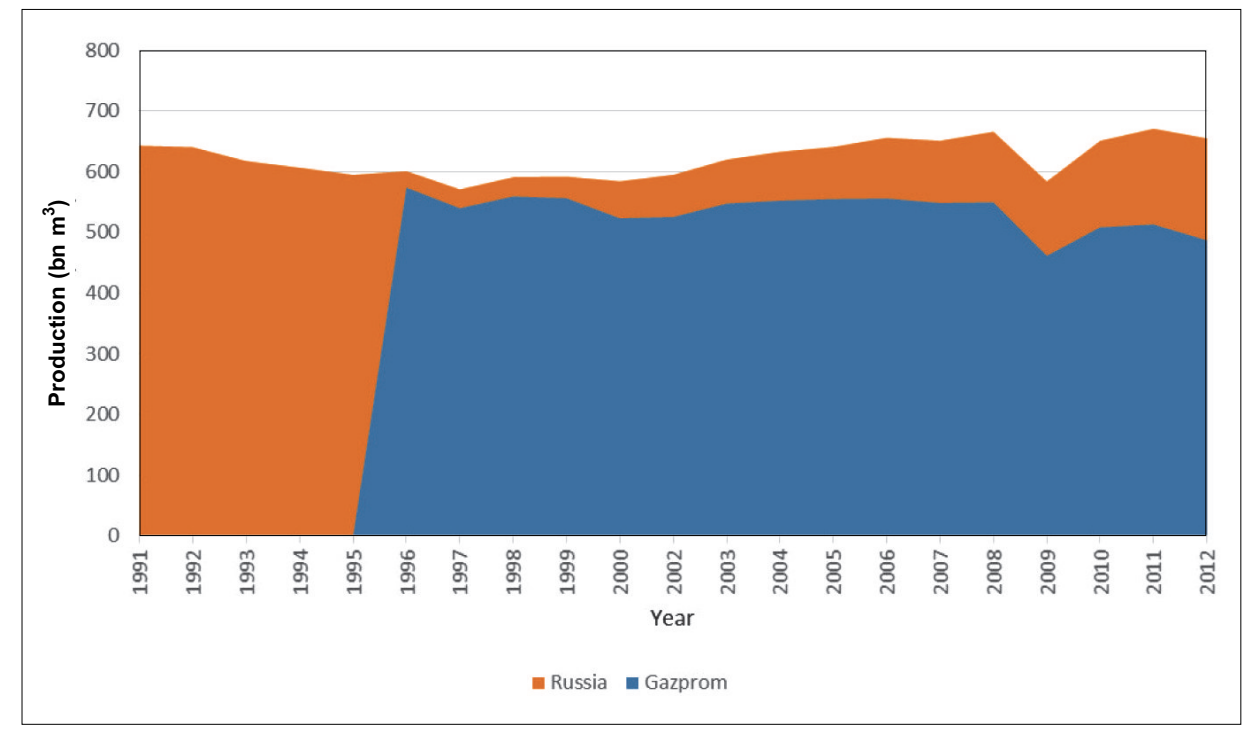

Fig. 2. Natural gas production in Russia (bn $\mathrm{m}^{3}$ )

Source: Российский статистический ежегодник, Gazprom.ru

After a few years of slow growth of gas production in Russia in 2003-2008, a rapid breakdown was observed in 2009. It was caused by the drop of gas demand on the domestic market and the situation on the European gas market, i.e.

- lower gas demand due to the global financial-economic crisis,

- aggressive sales policy of LNG suppliers,

- higher shale gas extraction in the USA.

During the last decade the participation of Gazprom on the Russian gas market decreased from $88.3 \%$ (2002) to $74.3 \%$ (2012), which was connected with, e.g. realization 
of projects of independent gas producers and oil companies, increasing the role of associated gas production, and unfavorable situation of international gas markets.

In the 2000s Gazprom launched the production on only two large fields: in 2001 the Zapolarnoe field discovered in 1965 and South Russian field discovered in 2007. The Yamalo-Nenets Autonomous Okrug still remained the main gas production center. In 2001 the Medvezhe, Urengoy and Yamburg fields gave 72\% of Gazprom production, however the level of their depletion was $83 \%, 62 \%$ and $48 \%$, respectively [2]. Another problem was the ageing of the pipeline network; the average age of Gazprom pipelines during the first presidency of Putin equaled to 22 years. Only $29 \%$ out of $153,000 \mathrm{~km}$ of major gas pipelines was under 10 years, 37\% 10-20 years, 20\% 20-33 years, $14 \%$ were over 33 years old (Fig. 3) [5]. Another factor hindering the further increase of this sector was the lack of funds for the investments, being a consequence of unfavorable investment climate and specific status of the monopolist in the Russian economy and politics [21].

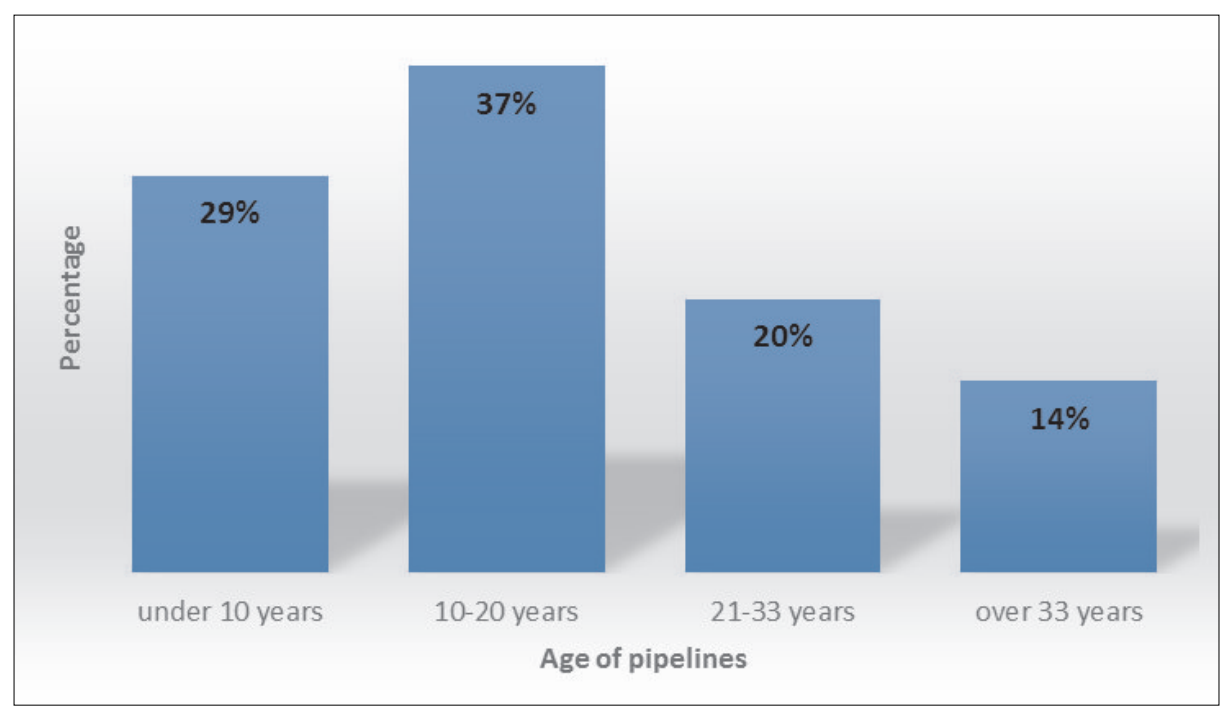

Fig. 3. Age of gas pipelines owned by Gazprom

For the sake of improving the financial condition of Gazprom in 2003-2010 the participation of excises and export duties was reduced from $26 \%$ to $16 \%$. The NDPI tax for gas production stabilized at a level of $147 \mathrm{RUB} / 1000 \mathrm{~m}^{3}$ and has not increased since 2006 . The budget plan for 2008-2010 assumed a fivefold increase of NDPI tax for gas, i.e. to 735 RUB, however the Gazprom authorities negotiated this. Finally since 2011 the tax was doubled [24].

Moreover, the position of Gazprom on the Russian market was reinforced thanks to the law act of 2006 guaranteeing it a monopolist position as an exporter of all kinds of gas, both pipeline gas and LNG ("On gas export", 18 July 2006) [1]. The export activity of 
Russian gas companies could not be realized on the basis of the "agency agreements" concluded with Gazprom Export, a go-between company for the contacts with foreign partners.

When in 2008 Dmitry Medvedev, former chairman of Gazprom Board of Directors, became President, the Concern was granted new licenses for extraction. Ever since the capitalization of the gas monopolist has been constantly increasing. In the middle of 2008 A. Miller ensured that it is expected to reach a level of 1bn USD within 7 to 10 years time [11]. Then the World's gas prices were assumed to reach a level of $1000 \mathrm{USD} / 1000 \mathrm{~m}^{3}$.

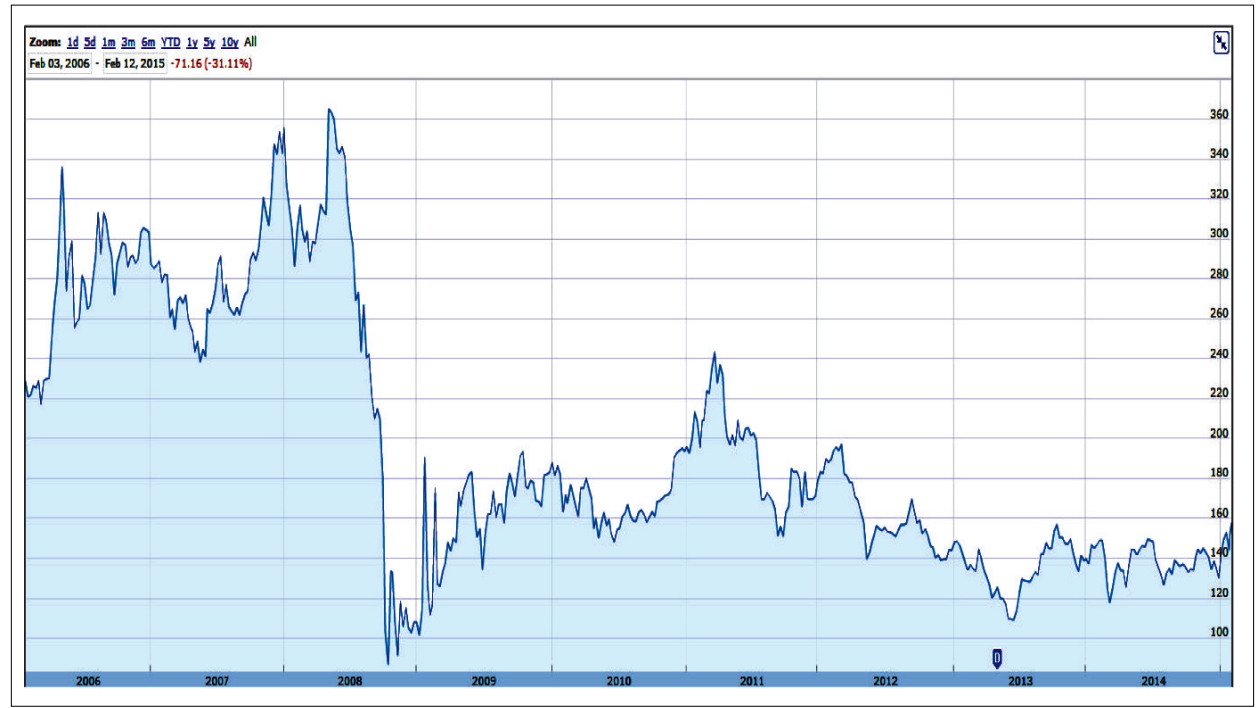

Fig. 4. Gazprom share price in 2006-2015 (RUB)

Source: Google Finance

The first signal that the role of Gazprom was weakening on the domestic market was the decision on breaking its position of a monopolist [20]. According to the amended export act of December 2013, now LNG can be exported by Gazprom and also by Rosneft and Novateka - Yamal-LNG Project. Furthermore, gas can be exported by companies having licenses, in which LNG installations were planned (as of 1 January 2013). Another company interested in the LNG sales is also Lukoil. According to the forecasts of the Ministry of Energy of the Russian Federation the LNG production should increase from $10 \mathrm{~m}$ to $50-60 \mathrm{~m}$ tons annually in the coming ten years [27].

Among the external factors which gave the most severe blow to the Russian giant and greatly contributed to the drop of capitalization to 77bn USD in the middle of 2013 (Fig. 4) are:

- World's crisis of 2008,

- shale gas revolution in the North America,

- higher LNG import to the European market. 


\subsection{Independent gas producers}

The Russian gas market is split into regulated and unregulated segment. Gazprom is the main supplier of blue gas to the State-controlled segment, while independent gas producers and suppliers are in the unregulated segment [30].

Attention should be paid to the fact that Gazprom holds the exclusive right to manage the Russian gas pipelines, which creates problems for other companies. In the 1990s apart from Gazprom there appeared other independent gas producers on the gas market (Novatek, Sibneftegaz, Nortgaz and Itera), or oil companies producing accompanying gas (LUKoiI, Surgutneftegaz, Rosneft, TNK-BP) (Fig. 5) [28].

The monopolist position of Gazprom over the last 20 years weakened the competitiveness of private companies. The giant controlled the gas network and regularly increased transmission charges. This was a signal to the remaining companies that only a close cooperation with the monopolist guarantees their existence on the market. In 1999-2000 another rapid increase of gas production by independent companies from $3.6 \mathrm{bn}$ to $30 \mathrm{bn} \mathrm{m}^{3}$ was observed. In 2000 a $10 \%$ participation of private companies in the Russian gas market was noted [15].

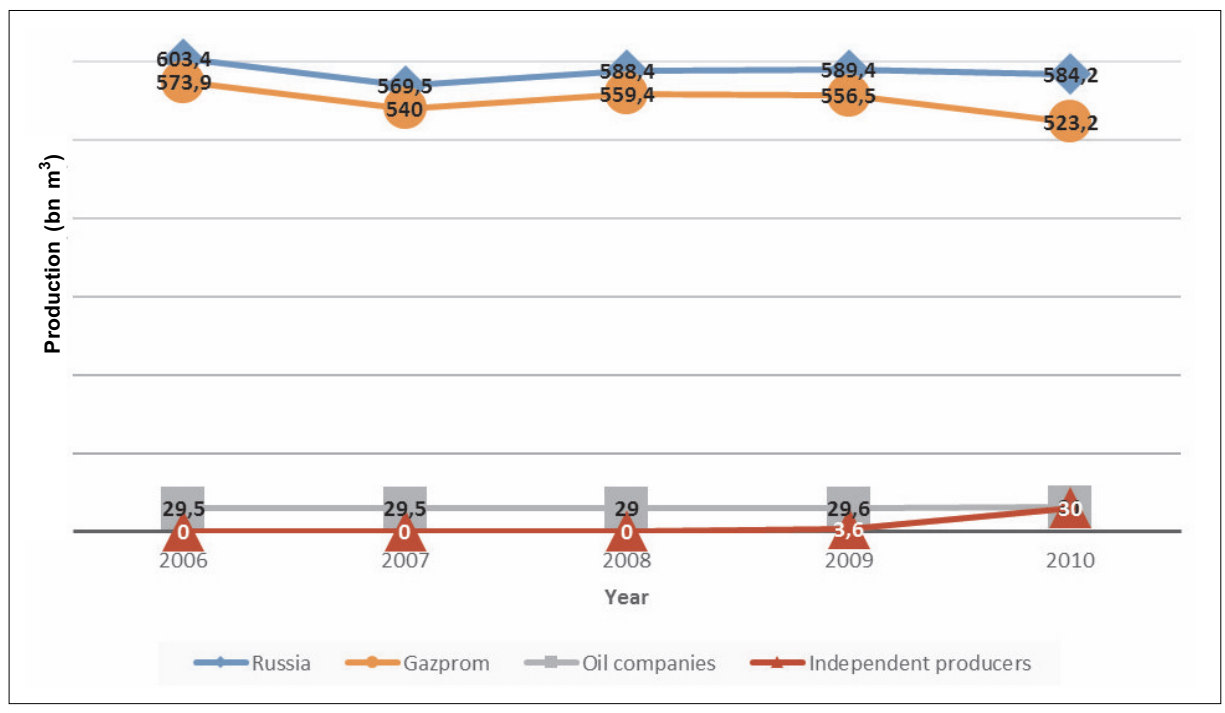

Fig. 5. Gas production in Russia in 1996-2000 (bn $\mathrm{m}^{3}$ )

Source: Нефтегазовая вертикаль 2002, № 6, с. 12-15

Despite the high export income, Gazprom did not manage to reach the gas production level of 1991 up to the year 2004. At the same time the independent gas producers, who were deprived of the export possibility, sold the gas only on the domestic market and were able to almost double their production in 1999-2004. The inability of increasing its production on the part of Gazprom as compared to the efficient development of independent companies 
proves the inefficiency of centralized State-dominated model of energy sector as compared to the economically mobile private energy sector.

After A. Miller started his presidency, Gazprom started to successively overtake the most valuable assets of independent companies, mainly Itera. In 2005 Gazprom overtook the control of the third biggest independent producer, i.e. Nortgaz, and in 2006 started a strategic partnership with the biggest private player, i.e. Novatek. Moreover, Gazprom persuaded LUKoil to sell part of its gas assets.

The main problem of independent gas companies is connected with the hindered access to the transmission pipelines. The Russian monopolist used to refuse all the transmission requests explaining that no free transmission capacities were available. In this situation the ability to legally sell gas at market prices of the private producers in the 1990s [18], was purely fictitious, because Gazprom used to buy off the raw mineral and export it at several times higher prices. As a consequence, in the early 2000s the profitability of independent companies and Gazprom was 3-4\% and 15-20\%, respectively [16]. Private companies were not treated leniently by the fiscal organs either; at that time their taxes equaled to $60 \%$, as compared to Gazprom with its 25-35\% [15]. The suggestion of extracting Gas Transportation System (Газотранспортная система) GTS from Gazprom and transforming it into an independent unit staying under the State control was rejected several times by Putin.

In autumn 2014 Igor Sechin, head of the biggest Russian oil company Rosneft demanded from the President of Russia a reform of the tariff system and change of order in which independent gas suppliers can use the monopolist's pipelines. Sechin emphasized that Gazprom allows independent suppliers to GTS at its discretion. Negotiations continue and companies finally are forced to send gas to Gazprom-operated underground gas storages. This leads to penalties and breaching of the contracts. Igor Sechin also observed that with the existing tariffs and the use of underground gas storages the gas sales in Russia are unprofitable. Moreover, the GTS gas transmission contracts are concluded for a periods under 5 years, whereas the production of hydrocarbons may go in tens of years and the consumer contracts are signed for 15-25 years. Gas transmission in Russia is more expensive than in America, Great Britain and Italy. In 2007 the tariff equaled to 1.4 USD/1000 $\mathrm{m}^{3}$ in America and 1.2 USD in Russia; in 2014 the situation almost did not change in the USA, whereas in Russia the tariff increased to 2 USD [7].

\section{STATE ACTIVITIES ORIENTED TO GAZPROM}

In the 1990s and in the beginning of the 2000s the role and participation of the State in the energy sector in Russia was not clearly defined. Undertaking numerous activities aimed at marketization of energy sector ${ }^{2}$, the stated tried to control many aspects of energy

2 1992-1993 - liberalization of prices for oil and oil derivatives, 1994-2004 - active privatization of oil companies, 1998 - liberalization of gas prices offered by independent producers. 
industry also by other activities, e.g. informal ban for private major pipelines, control over Gazprom. The history of this self-contradicting policy began in 1992 when the liberalization of prices was accompanied by maintaining regulated prices for energy products (Gazprom, RAO). The financial problems encountered by Gazprom in the 1990s were a derivative of, e.g. ambiguous relations and settlements with the government. On one hand the Concern was granted considerable tax relief, on the other one was obliged to direct considerable amounts of money to the State budget for current expenditures. Gradually, the government and the gas monopolist assumed an unofficial agreement through the force of which Gazprom paid taxes on the basis of current needs of the government, not based on the existing tax system [19]. Accordingly, in the 1990s Gazprom was an important institution supporting the government in crisis situations. The Company's reserves were used for solving political problems.

The new millennium brought the new changes in the relations between Gazprom and the State authorities. "Gazprom is more than a joint stock company. The entire economy of the country predominantly relies on the gas sector" 3 , these were the words of the new president Vladimir Putin. Two months later, in June 2000, he insisted on replacing Victor Chernomyrdin with confident Dmitry Medvedev on the position of a chairman of the Gazprom Board of Directors. In May 2001 he substituted Rem Viakhirev, heading Gazprom since the moment it was established in 1992, with Alexei Miller. At the same time the process of recapturing Company's assets, scraped in the 1990s, began. This able operation restored the control over Itera (gas company), Sibur (chemical holding) and Stroytransgas (construction of gas pipelines) [20].

The role of the State in the energy sector, and also activity of Russian authorities in the energy sector underwent significant transformation during Putin's second presidency. The new government headed by M. Fradkov importantly limited its participation in undertaking key decisions for the energy sector; the initiative was given to the President and his administration. This period is marked with increased intervening activity of Putin and his surrounding as far as economy, and before all in energy sector are concerned. These activities assumed both maintaining and reinforcing centralization of energy companies, establishing direct control of the State in these spheres of energy sector, where private proprietors used to dominate so $\mathrm{far}^{4}$. Ever since Gazprom was to be a tool for creating foreign policy to reinforce the position of Russia on the international arena ${ }^{5}$.

3 Quote from a website of the President of the Federation of Russia.

4 For instance, Yukos affair; official statements by Putin in 2003-2004, being a voice of disagreement to the market restructuring of Gazprom; demand on the part of Kremlin to have a supervision of energy sector transactions, direct foreign investments of the sector; overtaking energy assets in the former Soviet Union area by State companies, e.g. Gazprom, initiated by Kremlin and justified politically.

5 Idea of "energy superpower" presented during a meeting of "United Russia" in 2006 by President's advisor Vladislav Surkov. It assumes the use of the fuel-energy potential to reinforce the position of the Federation of Russia on international arena. 
When most of the assets lost in the 1990s were regained by Gazprom a new process took place, i.e. people representing the new deal started overtaking them. There were cooperants and business partners of the President of Russia when he worked in St. Petersburg mayoralty and served in KGB. Among them are, e.g. Gennady Timchenko, who bought Stroytransgas and Sibur companies for very symbolic money, and who also overtook control over Novatek - presently the biggest independent gas company in Russia. Since that time the activity of the government was directed to making Novatek a strong player on the Russian gas market. It is realized by granting the company tax relief or numerous concessions for Yamal gas deposits, thanks to which the Novatek confirmed resources increased six times from 690bn $\mathrm{m}^{3}$ (2008) to over $4 \mathrm{tr} \mathrm{m}^{3}$ (2011) within two years time. Thanks to the efforts Timchenko and his close relations with Putin, in 2013 Novatek obtained the right to individually export LNG when the export monopoly of Gazprom was limited [25].

In 2004 Bank Rossiya, controlled by Yury Kovalchuk - a friend of Putin from St. Petersburg times - overtook Sogaz (owned by Gazprom), one of the biggest insurance companies in Russia. In 2006 the latter bought a valuable asset from Gazprom, i.e. 75\% + 1 share of Lider company, managing pension fund and investment funds of Gazfond, which in turn became an owner of the controlling interest of Gazprombank. Moreover, Kovalchuk overtook control of the Gazprom-media holding (NTV, TNT, REN TV, Petersburg, 5-channel) [14].

After buying off construction assets for minimum prices, brothers Arkady and Boris Rotenberg - Putin's friends from childhood and judo sparing partners - created on this basis Stroygazmontazh company. Since 2008 the company has won most of the Gazprom tenders for the delivery of pipes and details to be used for pipelines construction of, e.g. Nord Stream, the cost of which turned out to be three times higher as compared to Europe's standards. The Stroygazmontazh also realized other multi milliard strategic projects for transmission pipelines, totally ignoring the tendering procedures, e.g. Sakhalin-Chabarovsk-Vladivostok, Dzhubga-Lazarevskoye-Sochi (Putin. Corruption 2). In 2010 the Rotenberg brothers took control over Gazprom Burenie, a company responsible for geological research, construction, maintenance of oil and gas wells and underground gas storages [25].

If at the end of the 1990s the controversial removal of assets from Gazprom was broadly commented by public and independent media, during Putin's presidency such issues were silenced.

\section{GAZPROM - CIS RELATIONS}

Energy problems in the Gazprom - CIS relations in the post-soviet period referred to a few most important issues:

- prices for fuels,

- liabilities to Gazprom,

- transmission infrastructure and transit charges,

- Russia in energy sectors of CIS countries. 
High energy consumption and economic inefficiency of the post-soviet countries in the 1990s caused their dependence on gas and oil supplies from Russia. In exchange for loyalty and acceptance of policy, Federation of Russia maintained low gas prices in CIS countries for ten or so years after the breakup of the Soviet Union. The prices were slightly higher than on the internal Russian market and much lower than offered to the Central and Western Europe countries. Natural gas played an important social function. It was perceived as an informal prerequisite of social stability, therefore its deliveries were subsidized by the State, which brought about unfavorable financial results for domestic operators.

Apparently the policy of low gas prices realized by Gazprom in CIS countries should favor paying the liabilities in time. Unfortunately more important economic needs had to be satisfied and the debt was increasing, consequently leading to the growth of a conflict with Ukraine, through the territory of which $95 \%$ of Russian gas was passing to the West and where over half of Gazprom-owned underground gas storages were located [10]. Each unpaid liability was burdened with a penalty equal to the value of the delivery [29]. The increasing debts caused conflicts and gas wars between Russia and CIS countries at that time. The debtors paid only $7 \%$ of their liabilities, the remaining part was bartered (metal, cement, food products).

The Orange Revolution in Ukraine (November-December 2004) and election of Viktor Yushchenko for president significantly deteriorated the Ukrainian-Russian relations. The Kremlin and Gazprom felt confused therefore undertook measures to undermine the new Ukrainian authorities. This situation triggered another increase of gas prices for the Ukrainian consumers "to the European level" (from $50 \mathrm{USD} / 1000 \mathrm{~m}^{3}$ in 2004 to $426 \mathrm{USD} / 1000 \mathrm{~m}^{3}$ in 2012) [8].

Two years later, the remaining countries of the eastern block were increased the price of gas, within the first stage of the Russian "energy superpower" concept. The beginning of the new gas prices in the post-soviet republics and the debt to Gazprom are correlated with the presence of Russia in energy sectors of these countries. Since the middle 1990s Gazprom used to undertake successive (though not always successful) attempts at taking control over gas sectors of the indebted countries. In 1998 Gazprom managed to overtake $50 \%$ plus one asset of Moldovagaz, a state company managing the Moldavia gas system [9]. The increasing debt to the Russian giant was another argument for Kiev to transfer Ukrainian gas pipelines, underground gas storages and petrochemical companies to Russia. The stage of realization of this plan was blocked by the Superior Council which banned the privatization of gas networks and the related infrastructure [29]. Attempts at seizing control over the Ukrainian Naftohaz have been undertaken up to date. In 2007 in exchange for being given a transitory period for gas price increases, Minsk agreed to transfer $50 \%$ of Beltransgaz assets to Gazprom. Beltransgaz is the owner of a transit gas pipeline transmitting Russian gas to the West. Treating Beltransgaz as a tool with which the Lukashenka regime could outbalance the total dependence on energy products, Belarus had struggled 
not to sell this strategic company to Russia for years [9]. In 2010 the gas price for the Belarusian customers was increased from 150 to $194 \mathrm{USD} / 1000 \mathrm{~m}^{3}$. A year later, when the second half of assets of the Belarusian operator was sold, the gas price was lowered to 165.5 USD $/ 1000 \mathrm{~m}^{3}$ [24].

The dependance of part of the CIS countries on Russian deliveries of energy products was limited to the control of transmission infrastructure linking the Russian gas provinces with Western Europe. By 1999, 95\% of Russian gas was transmitted to the West through the Ukrainian territory. Permanent gas conflicts between Moscow and Kiev made Russia search for new solutions limiting the role of Ukraine as a transit country. The launching of the Yamal gas pipeline (the first diversification project) was to reduce the dependence on Ukraine and increase the role of Belarus as a country through which Russian gas can be transferred. Nord Stream - running on the Baltic Sea bed from Russian Vyborg to German Lubmin is another diversification project which was to give warranty of uninterrupted deliveries of Russian gas. This gas pipeline of $55 \mathrm{mld} \mathrm{m}^{3}$ yearly capacity enabled Gazprom (controlling the Belarusian section of the Yamal pipeline) transmit considerable quantities of gas beyond the Polish gas pipeline system, though still using Ukrainian territory for transit purposes. Now Gazprom does not control the main transit pathway to the West Europe, i.e. Ukrainian gas pipelines (Brotherhood and transBalcans). After the failure of talks with Kiev on seizing control over the Ukrainian gas pipelines in 2012, Gazprom announced creating a consortium for the construction of two new lines of the Nord Stream. This plan has not been realized so far.

\section{CONCLUDING REMARKS}

The increase of oil prices on the international raw mineral markets in the early 2000s released Gazprom from the responsibility for supporting Russian economic stability at the expense of national gas sector. The new task of the Russian gas giant was to realize the concept of "energy superpower", i.e. use of fuel/energy potential for strengthening the position of Russia on the international arena. However, the events of 2014, i.e. Russia-Ukraine conflict and the resulting sanctions imposed by USA and Western countries called many of Gazprom projects into question. The Ukrainian crisis made Europe think of diversification of energy sources. In 2014 the Gazprom export to UE dropped down by $13.8 \%$ (to $121.3 \mathrm{mld} \mathrm{m}^{3}$ ) as compared to the previous year, thus repeating the result of 2010 , the poorest of the last 20 years [6]. The slowing down expansion of Gazprom on the European market made Russia look for new markets in Asia, where the prices for energy carrier are higher than in Europe.

The development of the LNG export would possibly improve the situation of Gazprom on the European market. However the Russian monopolist is new to the LNG market. The participation of LNG on the background of entire Russian gas production does not 
exceed 4\%. At present only Sakhalin-2 (9.6 mln ton) Gazprom (51\%), Mitsui, Mitsubishi and Shell [27] are operational. Moreover Gazprom also realizes Baltic-LNG Project (5 mln ton) and Vladivistok-LNG Project (to $8 \mathrm{mln}$ ton) [30]. They are to be launched in 2018 though the latter can be withheld on behalf of gas deliveries to China.

\section{REFERENCES}

[1] Федеральный закон от 18 июля 2006 г. № 117-Ф3 “Об экспорте газа”.

[2] Газ из глубины, «Нефть и капитал» 2008, No 8.

[3] “Газпром” не сдает внутренний рынок Монополия рассчитывает сохранить свою долю, невзирая на конкурениию, 29.05.2013, www.kommersant.ru/doc/ 2199601

[4] «Газпром» получил скидку в прогнозе, 19.09.2014, www.kommersant.ru/doc/ 2570081.

[5] «Газпром» в каждом доме, Нефть и капитал, 2003,№ 6.

[6] «Газпром» теряет Европу, 16.02.2015, www.kommersant.ru/doc/2668750.

[7] Глава Роснефти Игорь Сечин предложил Дмитрию Медведеву усилить контроль за «Газпромом», 16.09.2014, www.oilcapital.ru/company/252307.html.

[8] Гриб Н.: Газовый император. 2009, Москва.

[9] Gromadzki G., Konończuk W.: Energetyczna gra. Ukraina, Mołdawia i Białoruś miedzy Unia a Rosja. Fundacja im. Stefana Batorego, Warszawa 2007.

[10] Joskot-Strachota A.: Rosyjski gaz dla Europy. OSW, Warszawa 2006.

[11] Миллер нацелился на триллион, 23.06.2008, www.vz.ru/economy/2008/6/23/ 180201.html.

[12] Милов В., Селивахин И.: Проблемь энергетической политики. Рабочие материалы Московского центра Карнеги, 2005.

[13] МЭА.: Энергетическая политика России. Обзор 2002 года, Париж 2002.

[14] Немцов Б., Милов В.: Путин и Газпром. Независимый экспертный доклад, www.nemtsov.ru/.

[15] «Нефтегазовая вертикаль» 2002, No16.

[16] «Нефтегазовая вертикаль 2003, No 8.

[17] «Нефтегазовая вертикаль» 2002, o 8.

[18] «О внесении изменений в Постановление Правительства РФ «О мерах по упорядочению государственного регулирования цен (тарифов)» от 7 марта 1995 года, о 239.

[19] Paniuszkin W., Zygar M.: Gazprom - rosyjska broń. W.A.B., Warszawa 2008.

[20] Paszyc E.: Osłabienie pozycji Gazpromu na rosyjskim rynku gazu. Komentarze OSW, nr 70, 2012, 1-9.

[21] Paszyc E., Wiśniewska I.: Gospodarka rosyjska pod rzqdami Putina. Czynniki wzrostu i hamulce rozwoju. Prace OSW, Ośrodek Studiów Wschodnich, Warszawa 2005. 
[22] Постановление Правительства РФ от 28 мая 2007 г. № 333 «О совершенствовании государственного регулирования цен на газ».

[23] Постановление Правительства РФ от 31 декабря 2010 г. № 1205 «О совершенствовании государственного регулирования цен на газ».

[24] Пусенкова Н.: Российский «Газпром» в газпромовской России. 2010, www. ru-90.ru/node/1320.

[25] Путин. Коррупщия. Независимый экспертный доклад, Москва 2011, www.putinitogi.ru/putin-i-korruptsiya/.

[26] Россия должна Газпрому почти столько же, сколько Украина. 07.11.2014, www.vedomosti.ru/companies/news/35696951/rossiya-dolzhna-gazpromu-pochtistolko-zhe-skolko-ukraina

[27] Россия планирует удвочть поставки СПГ в Японию. 27.10.2014, www.oilcapital.ru/export/255332.html

[28] Саакян Ю.: Настоящее и будущеее независимых производителей газа: проблемы и перспективы роста. Федеральный справочник. Топливно-энергетический комплекс России, No10.

[29] Szeptycki A.: Stosunki pomiędzy Federacja Rosyjska i Ukraina w sektorze gazowym. [in:] Wyciszkowski E. (red.), Geopolityka rurociagów. Wspótzależność energetyczna a stosunki międzypaństwowe na obszarze postsowieckim, Warszawa 2008, s. $97-135$.

[30] www.gazprom.ru.

[31] www.oilcapital.ru/export/255332.html. 